\title{
Association between Estrogen Receptor Gene Polymorphisms and Depression in Post-Menopausal Women: A Preliminary Study
}

\author{
Jung Jin Kim ${ }^{\bowtie}$, Chi Un Pae', Mi Ran Kim², Jung Ah Min, \\ Kyung Hee Kim', Chang Uk Lee ${ }^{1}$, Chul Lee ${ }^{1}$ and In Ho Paik ${ }^{1}$ \\ ${ }^{1}$ Departments of Psychiatry and ${ }^{2}$ Gynecology, The Catholic University of Korea College of Medicine, Seoul St. Mary's Hospital, Seoul, Korea
}

\begin{abstract}
Post-menopausal women experience variable biological and psychological changes. The effect of reduced levels of estrogen can effect on post-menopausal depression. Estrogen triggers physiological responses by binding to the estrogen receptor (ER). Two subtypes of ER, $\mathrm{ERa}$ and ERb are now known. We investigated the significance of ERa and ERb polymorphisms and post-menopasal depression in this study. Forty three women with post-menopausal depression and 63 post-menopausal women without depression as normal controls were recruited. Polymerase chain reaction-restriction fragment length polymorphism method was used to investigate genotypes of ERa and ERb polymorphisms. Genotypes of PvuII and XbaI polymorphism of ERa receptor were significantly different in patients with postmenopausal depression comparing with controls. Genotypes of ERb did not show association with post-menopausal depression. Our study showed that ERa receptor polymorphism had an association with depression in post-menopausal women. It suggests that investigation of ER genes and their functions might be important for understanding pathophysilogical mechanism of post-menopausal depression.
\end{abstract}

Psychiatry Investig 2010;7:224-227

Key Words Menopause, Depression, Estrogen, Receptor, Polymorphism.

\section{INTRODUCTION}

Women are vulnerable to depression especially along with menopause. ${ }^{1}$ Women who had reproductive cycle event-related depression such as premenstrual dysphoric disorder, perimenopausal depression and postpartum depression reported a stronger family history of mental illness than other depressed women. ${ }^{2}$ It suggests unique characteristics and perhaps a more biologically driven illness for this subgroup of depressed women. ${ }^{2}$

Post-menopausal women experience variable biological and psychological changes. The effect of reduced levels of estrogen can effect on post-menopausal depression in susceptible women. ${ }^{3,4}$ Estrogen passes the blood-brain barrier, and receptors for them are abundant in brain areas such as limbic

Received: February 26, 2010 Revised: May 29, 2010

Accepted: June 17, 2010 Available online: August 13, 2010

$\triangle$ Correspondence: Jung Jin Kim, MD, PhD

Department of Psychiatry, The Catholic University of Korea College of Medicine, Seoul St. Mary's Hospital, 505 Banpo-dong, Seocho-gu, Seoul 137-701, Korea Tel: +82-2-2258-6084, Fax: +82-2-594-3870, E-mail: jjean@catholic.ac.kr

(a) This is an Open Access article distributed under the terms of the Creative Commons Attribution Non-Commercial License (http://creativecommons.org/licenses/bync/3.0) which permits unrestricted non-commercial use, distribution, and reproduction in any medium, provided the original work is properly cited. structure important for the regulation of emotions, cognition and behavior. ${ }^{5-8}$ The fact that men and women differ with respect to the prevalence of depression may possibly also reflect an influence of estrogen on human behavior. ${ }^{6}$

Estrogen triggers physiological responses by binding to a nuclear receptor protein, the estrogen receptor (ER). ERs are nuclear receptor proteins that have an estrogen binding domain and a deoxyribonucleic acid (DNA) binding domain. ${ }^{9}$ The ER is classified as a class 1 member of the superfamily of nuclear hormone receptors. ${ }^{10}$ Two subtypes of ER are now known, ERa and ERb. ${ }^{11}$ The ERa gene is localized on chromosome 6q25.1, ${ }^{12}$ and the ERb gene is localized on chromosome $14 \mathrm{q} 22-24{ }^{13}$ Recently, several genetic variants of Era and ERb gene were described.

The association of genetic polymorphisms of ER and psychiatric disorders have been the subject of increasing interest. ${ }^{14}$ However, given the important role of estrogen for brain function and abrupt change of it in postmenopausal period, there are relatively few studies so far have addressed the possible influence of ER polymorphism with respect to susceptibility to depression in postmenopausal women. ${ }^{15-18}$

Therefore, we investigated the significance of ERa and ERb polymorphisms and post-menopasal depression in this study. 


\section{METHODS}

Forty three women with post-menopausal depression and 63 post-menopausal women without depression as normal controls in Korean population were recruited for this study. All of them were between 45 and 60 years and were not under psychiatric treatment. Post-menopausal women who have intact uterus and more than 1 ovary, no sex steroid hormone use in the previous 3 months, absence of pregnancy, and previous regular menstrual cycle were enrolled. In addition to menstruation history, serum FSH, LH, and estradiol (E2) were tested to confirm postmenopausal period in all the women. Postmenopausal women with Beck Depression Inventory (BDI) scores over $21(39.17 \pm 11.04)$ were evaluated and included as postmenopausal depression group if they were diagnosed as major depressive disorder or depressive disorder, NOS by DSM-IV criteria by psychiatrist. They were not under psychiatric treatment. All the normal controls were under BDI score $21(8.61 \pm 2.25)$ and they were evaluated by psychiatrist to be determined as they did not have any kind of depressive disorder. They were also performed by other scales such as Hamilton Depression Rating Scale, Montgomery-Asberg Depression Rating Scale, and State-Trait Anxiety Inventory. Subjects with neurological disorder, endocrine disorder, and other psychiatric disorder were excluded in this study. Written informed consent was obtained from all the subjects.

Genomic DNA from the peripheral blood was extracted using DNA Isolation kit (Bioneer, Daejeon, Korea) following the manufacturer's protocol. ERa genotypes were determined with polymerase chain reaction-restriction fragment length polymorphism (PCR-RFLP) method reported earlier ${ }^{14}$ with some modification. After PCR, 1.3-kb fragments were digested by PvuII and XbaI. The primers for analysis of ERb genes were ERb genotypes were determined with a PCR-RFLP method reported earlier. ${ }^{18}$ After PCR, the products of 156 and 307 bp were digested by RsaI and AluI, respectively. The genotyping were performed in duplicate manner and interpreted by two blind researchers.

The characteristics of patients by ER genotypes were examined by means of a one-way analysis of variance for continuous variables and by chi-square analysis for discrete variables. The significance level for all statistical tests was 0.05 . The statistical analyses were performed using Statistical Package for the Social Sciences (SPSS) 12.0. for Windows (SPSS Inc., Chicago, IL, USA).

\section{RESULTS}

There were no differences in age distributions between the patient ( $49.9 \pm 6.7 \mathrm{yrs})$ and control groups ( $50.0 \pm 7.3 \mathrm{yrs})$. Age was
Table 1. Genotypes of estrogen receptor polymorphisms in patients with post-menopausal depression and normal controls

\begin{tabular}{lcccc}
\hline & & $\begin{array}{c}\text { Patients } \\
(\mathrm{N}=43)\end{array}$ & $\begin{array}{c}\text { Controls } \\
(\mathrm{N}=63)\end{array}$ & p value \\
\hline PvaII, N(\%) & PP & $11(25.6)$ & $18(28.6)$ & $0.001^{*}$ \\
& Pp & $26(60.5)$ & $18(28.6)$ & \\
& pp & $6(13.9)$ & $27(42.8)$ & \\
XbaI, N(\%) & XX & $7(16.3)$ & $6(9.5)$ & $0.000^{\dagger}$ \\
& Xx & $34(79.1)$ & $18(28.6)$ & \\
& xx & $2(4.6)$ & $39(61.9)$ & \\
AluI, N(\%) & AA & $22(51.2)$ & $39(61.9)$ & 0.345 \\
& Aa & $21(48.8)$ & $23(36.5)$ & \\
& aa & $0(0.0)$ & $1(1.6)$ & \\
RsaI & RR & $19(44.2)$ & $35(55.6)$ & 0.442 \\
& Rr & $20(46.5)$ & $25(39.7)$ & \\
& rr & $4(9.3)$ & $3(4.7)$ & \\
\hline
\end{tabular}

${ }^{*} \chi^{2}=13.204, \mathrm{df}=2,{ }^{\dagger} \chi^{2}=35.894, \mathrm{df}=2$

not associated with genotypes of ERa and ERb polymorphism.

The Hardy-Weinberg equilibrium (H-W-E) of genotypes of ERa and ERb showed some deviation [controls of PvuII ( $p=0.00094)$, controls of XbaI ( $p=0.00008)$, Patients of XbaI ( $p=0.00038)$, patients of AluI ( $p=0.034)]$. Levels of linkage disequilibrium between the polymorphisms of ERa and ERb in controls were $\mathrm{D}^{\prime}=0.2167$ and $\mathrm{D}^{\prime}=0.01129$.

Genotypes of PvuII and XbaI polymorphism of ERa receptor were significantly different in patients with post-menopausal depression comparing with controls $\left(\chi^{2}=13.204, \mathrm{df}=2\right.$, $\mathrm{p}=0.001 ; \chi^{2}=35.894, \mathrm{df}=2, \mathrm{p}=0.000$, respectively, Table 1$)$. AluI and RsaI genotypes of ERb did not show association with postmenopausal depression (Table 1). For clinical variables of postmenopausal depression, no clinical variables were related with genotypes of ER polymorphisms. (Data not shown) The power of a sample to detect the differences between the alleles was calculated by considering an alpha value of 0.05 , two tailed. Using these parameters, the sample was estimated to have a power $(0.80)$ to detect a small to small effect size $(\mathrm{w}=0.12)$, which corresponded to a difference of approximately $13 \%$ in the two alleles between the two groups.

\section{DISCUSSION}

The two subtypes of ER (ERa and ERb) differ with respect to tissue distribution and coregulator interactions. ${ }^{19,20}$ TA repeat located upstream from exon 1 of ERa may influence the tissue specific expression of the ERa gene. ${ }^{6}$ The two common polymorphisms such as the PvuII (T/C; rs2234693) in the 5' region of the gene and $\mathrm{XbaI}$ (A/C; rs9340799) polymorphisms in intron 1 are in strong linkage disequilibrium with this repeat. Also, PvuII single nucleotide polymorphism (SNP) pro- 
duces a binding site for a specific transcription factor that may affect gene expression. ${ }^{21}$ The functional polymorphism of ERb was not identified yet, and there are two common SNPs such as AluI at position 1730 (G/A; rs4986938) in the 3' untranslated region and RsaI silent mutation at position 1082 (G/A; rs1256049) $)^{22}$ in exon 5.

In this study, ERa receptor polymorphisms were strongly associated with depression in post-menopausal women. Considering PvuII and XbaI position of ERa might influence expression of ERa gene as mentioned above, these results showed the importance of functions of ERa polymorphisms in postmenopausal depression. Otherwise, ERb polymorphism was not associated with post-menopausal depression. The two polymorphisms examined in this study have not functional expression. Further research of ERb should be evaluated in post-menopausal depression along with identification of functional polymorphisms.

To our knowledge, this is the first case-control study of ER polymorphisms and post-menopausal depression. The influence of the ER polymorphism on physical and emotional symptoms of post-menopausal women has been insufficiently studied.

A few previous studies were performed to examine the relationship of ER receptor polymorphisms and postmenopausal depression. Malacara et al. ${ }^{17}$ reported that ERa polymorphisms (PvuII and XbaI) was not associated with emotional symptoms in post-menopausal women. In a cohort study, Tiemeier et al..$^{15}$ also examined the same ERa polymorphisms and found no association with depressive symptoms in women over 55 years. Instead, they found an association of an ERa with anxiety symptoms unlike our results. Kravitz et al. ${ }^{18}$ analyzed 4 SNPs of ERa and ERb in pre- and perimenopausal depression and found no association with depressive symptoms and those SNPs, although their SNPs were different with our study except PvuII of ERa. Majority of the subjects in previous study were Caucasians and they did not include normal control samples. Ethic and socio-cultural and environmental factors are involved in the appearance or symptoms of post-menopausal depression. ${ }^{23}$

Considering relatively small sample size of our study, which may affect deviation of H-W-E and different genotype distribution of ERa polymorphisms in Korean population, ${ }^{24}$ further studies with larger samples and different ethnic populations are recommended to elucidate the function of ER polymorphisms and depression in post-menopausal period. Also, given that a single polymorphism in a single gene could not exert any major impact on the activity of the sex steroids and on aspects of the phenotype that are under the influence of these hormones, ${ }^{6}$ diverse genetic studies with genes involving estrogen function is needed to elucidate pathophisiogic mechanism of postmenopausal depression.

\section{Acknowledgments}

This work was supported by the Korea Research Foundation Grant funded by the Korean Government (MOEHRD) (KRF-2006-E-00053).

\section{REFERENCES}

1. Cohen LS, Soares CN, Vitonis AF, Otto MW, Harlow BL. Risk for new onset of depression during the menopausal transition: the Harvard study of moods and cycles. Arch Gen Psychiatry 2006;63:385-390.

2. Gregory RJ, Masand PS, Yohai NH. Depression across the reproductive life cycle: correlations between events. Prim Care Companion J Clin Psychiatry 2000;2:127-129.

3. Steiner M, Dunn E, Born L. Hormones and mood: from menarche to menopause and beyond. J Affect Disord 2003;74:67-83.

4. Freeman EW, Sammel MD, Liu L, Gracia CR, Nelson DB, Hollander L. Hormones and menopausal status as predictors of depression in women in transition to menopause. Arch Gen Psychiatry 2004;61:62-70.

5. McEwen BS, Alves SE. Estrogen actions in the central nervous system. Endocr Rev 1999;20:279-307.

6. Westberg L, Eriksson E. Sex steroid-related candidate genes in psychiatric disorders. J Psychiatry Neurosci 2008;33:319-330.

7. Zhao L, Wu TW, Brinton RD. Estrogen receptor subtypes alpha and beta contribute to neuroprotection and increased Bcl-2 expression in primary hippocampal neurons. Brain Res 2004;1010:22-34.

8. Ostlund H, Keller E, Hurd YL. Estrogen receptor gene expression in relation to neuropsychiatric disorders. Ann N Y Acad Sci 2003;1007: 54-63.

9. Potter JD, Cerhan JR, Sellers TA, McGovern PG, Drinkard C, Kushi LR, et al. Progesterone and estrogen receptors and mammary neoplasia in the Iowa Women's Health Study: how many kinds of breast cancer are there? Cancer Epidemiol Biomarkers Prev 1995;4:319-326.

10. Mangelsdorf DJ, Thummel C, Beato M, Herrlich P, Schütz G, Umesono K, et al. The nuclear receptor superfamily: the second decade. Cell 1995;83:835-839.

11. Kuiper GG, Enmark E, Pelto-Huikko M, Nilsson S, Gustafsson JA. Cloning of a novel receptor expressed in rat prostate and ovary. Proc Natl Acad Sci U S A 1996;93:5925-5930.

12. Menasce LP, White GR, Harrison CJ, Boyle JM. Localization of the estrogen receptor locus (ESR) to chromosome 6q25.1 by FISH and a simple post-FISH banding technique. Genomics 1993;17:263-265.

13. Enmark E, Pelto-Huikko M, Grandien K, Lagercrantz S, Lagercrantz J, Fried G, et al. Human estrogen receptor beta-gene structure, chromosomal localization, and expression pattern. J Clin Endocrinol Metab 1997;82:4258-4265.

14. Cai Q, Shu XO, Jin F, Dai Q, Wen W, Cheng JR, et al. Genetic polymorphisms in the estrogen receptor alpha gene and risk of breast cancer: results from the Shanghai Breast Cancer Study. Cancer Epidemiol Biomarkers Prev 2003;12:853-859.

15. Tiemeier H, Schuit SC, den Heijer T, van Meurs JB, van Tuijl HR, Hofman A, et al. Estrogen receptor alpha gene polymorphisms and anxiety disorder in an elderly population. Mol Psychiatry 2005;10:806-807.

16. Weel AE, Uitterlinden AG, Westendorp IC, Burger H, Schuit SC, Hofman A, et al. Estrogen receptor polymorphism predicts the onset of natural and surgical menopause. J Clin Endocrinol Metab 1999;84: 3146-3150.

17. Malacara JM, Pérez-Luque EL, Martínez-Garza S, Sánchez-Marín FJ. The relationship of estrogen receptor-alpha polymorphism with symptoms and other characteristics in post-menopausal women. Maturitas 2004;49:163-169.

18. Kravitz HM, Janssen I, Lotrich FE, Kado DM, Bromberger JT. Sex steroid hormone gene polymorphisms and depressive symptoms in women at midlife. Am J Med 2006;119(9 Suppl 1):S87-S93.

19. Nilsson S, Mäkelä S, Treuter E, Tujague M, Thomsen J, Andersson G, et al. Mechanisms of estrogen action. Physiol Rev 2001;81:1535-1565.

20. Lonard DM, O'Malley BW. The expanding cosmos of nuclear receptor 
coactivators. Cell 2006;125:411-414.

21. Herrington DM, Howard TD. ER-alpha variants and the cardiovascular effects of hormone replacement therapy. Pharmacogenomics 2003; 4:269-277.

22. Rosenkranz K, Hinney A, Ziegler A, Hermann H, Fichter M, Mayer H, et al. Systematic mutation screening of the estrogen receptor beta gene in probands of different weight extremes: identification of several genetic variants. J Clin Endocrinol Metab 1998;83:4524-4527.
23. Malacara JM, Canto de Cetina T, Bassol S, González N, Cacique L, Vera-Ramírez ML, et al. Symptoms at pre- and postmenopause in rural and urban women from three States of Mexico. Maturitas 2002;43:11-19.

24. Choi TY, Kee BS, Lee MK, Park AJ, Kwak KH, Nam BY, et al. Interaction between estrogen receptor 1 and the epsilon 4 allele of apolipoprotein E in Korean schizophrenic patients. J Korean Neuropsychiatr Assoc 2002;41:831-846. 